\title{
OPTIMALISASI WAKAF PRODUKTIF SEBAGAI UPAYA PEMBANGUNAN DAN PEMBERDAYAAN EKONOMI MELALUI WISATA LOKAL
}

\author{
Mohammad Zainuri ${ }^{1}$ \\ Aliful Muhlis ${ }^{2}$ \\ Faridatur Rosyidah ${ }^{3}$ \\ ${ }^{123}$ JurusanEkonomi Syariah, Fakultas Ekonomi dan Bisnis Islam, IAIN Madura, Pamekasan, \\ Indonesia \\ Email: zainurimohammad263@gmail.com,muhlisalvarez89@gmail.com, faridaturrosyidah2@gmail.com
}

\begin{abstract}
Introduction: Waqf has a strategic economic dimension in empowering and increasing economic productivity if managed properly and with incentives. Productive waqf is a scheme for managing waqf donations from the people, namely by making these donations productive so that they are able to produce a sustainable surplus.

Methods: This study uses a qualitative research method with a descriptive approach. The type of data used is secondary data. The techniques used in data collection in this research include literature study, documentary, discussion, and intuitive-subjective.

Result: Tourism is one of the important assets to help support the economy of a country. Each country continues to try to take advantage of the existing potential to attract tourists to visit their country. So that tourism can contribute a lot in Indonesia in various fields, especially in the economic field. However, there are several tourist destinations that have not been managed properly due to the lack of funds to support these facilities, so it is necessary to optimize funds to provide concrete solutions in increasing tourism potential so that community economic empowerment is increasing. So that the existence of productive waqf can be an opportunity for optimizing tourism in order to achieve economic empowerment.

Conclusions and suggestions: Optimizing productive waqf aims to empower the people's economy. Where productive waqf can assist in the development of coastal tourism by optimizing facilities that can attract visitors so that with the existence of productive waqf it is expected to be able to support sustainable development in the tourism sector so as to reduce economic problems that often occur in the community, such as lack of employment and poverty. .
\end{abstract}

Keywords: productive waqf, economic empowerment, tourism.

\section{PENDAHULUAN}

Kemiskinan merupakan salah satu masalah sosial serius sekaligus suatu tantangan pembangunan yang dihadapi oleh setiap negara termasuk Indonesia. Jawa Timur merupakan provinsi yang walaupun sebagai kontributor kapasitas ekonomi nomor dua 
tertinggi di Indonesia, akan tetapi tingkat kemiskinannya masih berada di atas rata-rata nasional. Selama tiga tahun terakhir, sumbangsih ekonomi Jawa Timur berada secara konsisten di angka 14,6 persen. Satu peringkat di bawah DKI Jakarta dengan sumbangsih di kisaran 17,3 hingga 17,6 persen di rentang yang sama. Namun jika dilihat dalam konteks kemiskinan, persentase kemiskinan Jawa Timur sebesar 10,2 persen pada bulan September 2019, 11,46 persen pada September 2020, dan 11,40 persen pada bulan Maret 2021. Angka-angka tersebut konsisten selalu berada di atas angka rata-rata nasional yang sebesar 9,22 persen, 10,19 persen, dan 10,14 persen di masing-masing tahun yang sama. ${ }^{1}$ Pulau Madura merupakan salah satu kepulauan di Jawa Timur yang terdiri dari empat kabupaten yaitu Bangkalan, Sampang, Pamekasan, dan Sumenep yang saat ini masih tergolong daerah tertinggal dibanding wilayah sekitar. Hal tersebut tercermin dari pendapatan perkapita masih rendah pada tahun 2016 yakni, Kabupaten Bangkalan sebesar Rp. 20.758, Sampang sebesar Rp. 17.140, Pamekasan sebesar Rp. 15.833, dan Sumenep sebesar Rp. 26.902. Jika dibandingkan dengan pendapatan perkapita Kabupaten/Kota di Jawa Timur. Perbedaan nilai pendapatan perkapita tersebut merupakan indikator lain yang menunjukan tingkat kemakmuran di daerah pulau Madura masih rendah. ${ }^{2}$

Wakaf merupakan salah satu ibadah yang bercorak sosial ekonomi cukup penting. Dalam sejarah Islam klasik, wakaf telah memberikan peran yang sangat signifikan dalam meningkatkan kesejahteraan kaum muslimin, baik di bidang pendidikan, pelayanan sosial, pelayanan kesehatan dan kepentingan umum, kegiatan keagamaan, pengembangan ilmu pengetahuan serta peradaban Islam secara umum. Melihat wakaf secara historis, sesungguhnya telah mengajarkan umat Islam akan pentingnya sumber ekonomi yang terus menerus guna menjamin berlangsungnya kesejahteraan di masyarakat. Wakaf sebagai instrumen ekonomi yang memberi kehidupan bagi pengelolanya dan masyarakat. ${ }^{3}$

Pengelolaan wakaf di Indonesia kurang mengarah pada pemberdayaan ekonomi umat dan hanya cenderung pada kegiatan ibadah yang lazim, seperti untuk masjid, musholla, sekolah, madrasah, pondok pesantren, dan makam. Hal tersebut karena keterbatasan pemahaman tentang wakaf, sehingga dapat dikatakan bahwa di Indonesia saat ini potensi wakaf sebagai sarana berbuat kebajikan bagi kepentingan umat belum dikelola dan dapat didayagunakan secara maksimal dalam ruang lingkup nasional. ${ }^{4}$

\footnotetext{
${ }^{1}$ Zulfakhri Auzar, "Kemiskinan, Gender, dan Covid-19 Jatim: Feminization of Poverty, Multiple Pandemic, and Feminization of Pandemic" 1 (2021): 250.

2 Mohammad Wahed, "PEMETAAN POTENSI EKONOMI SEKTORAL DAN ESTIMASI PERTUMBUHAN EKONOMI KABUPATEN PAMEKASAN," Jurnal Ekonomi dan Bisnis 5, no. 1 (13 April 2019): 1, https://doi.org/10.35590/jeb.v5i1.685.

${ }^{3}$ Veithzal Rivai Zainal, "PENGELOLAAN DAN PENGEMBANGAN WAKAF PRODUKTIF" 9, no. 1 (2016): 2.

${ }^{4}$ Nailis Sa'adah dan Fariq Wahyudi, "Manajemen Wakaf Produktif: Studi Analisis Pada Baitul Mal Di Kabupaten Kudus" 4 (2016): 335.
} 
Kabupaten Pamekasan dirancang untuk menjadi pusat kegiatan Madura dan Kepulauan karena kabupaten ini memiliki potensi pendukung yang memadai. sarana dan prasarana umum di Kabupaten Pamekasan juga cukup memadai, di samping iklim investasi di Pamekasan juga baik, dan kebijakan pemerintah daerah memang sangat proinvestasi. Potensi pendukung yang juga bisa menjadi prospek investasi adalah industrial an wharehouse area, Pantai Talang Siring di Desa Kecamatan Larangan, Pantai Jumiang di Kecamatan Pademawu, serta objek wisata mangrove, selain itu, kampung batik di Desa Klampar, Kecamatan Proppo, Waru Market Centre di Kecamatan Waru, tembakau Madura dan produksi garam juga menjadi peluang investasi bagi investor yang hendak menanamkan modalnya di kabupaten berpenduduk sekitar 800 ribu jiwa lebih ini.

Pada era globalisasi saat ini pariwisata menjadi salah satu aspek penting terhadap kemajuan suatu negara. Setiap negara terus berusaha untuk memanfaatkan potensi yang ada untuk menarik wisatawan berkunjung ke negeranya. Begitu pula dengan Indonesia dimana pariwisata merupakan sektor yang cepat berkembang dan dianggap sebagai salah satu sektor ekonomi yang dapat diperhitungkan. ${ }^{5}$

Tata kelola dalam sektor pariwisata haruslah dilakukan secarabijaksana, karena apabila sektor pariwisata tidak dikelola secara benar akan berpotensi menimbulkan problem ataudampak negatif terhadap kehidupan sosial,ekonomi, dan lingkungan. Menurut Retnowati seperti yang dikutip oleh Hidayat, mengatakan bahwa adanyaaktivitas agroekowisata (pariwisata) diharapkan dapat memberikan manfaat kepada masyarakat setempat dengan pembukaan lapangan kerja, kesempatanberusaha, dan pendanaan yang di serap kembali dalam bentuk proyek-proyekpembangunan daerah. ${ }^{6}$

Salah satu Kabupaten yang memiliki banyak daerah tujuan wisata yaitu Kabupaten Pamekasan yaitu kurang lebih sebanyak 20 objek dan tujuan wisata yang dapat dimanfaatkan oleh para wisatawan berlibur.Akan tetapi dengan banyaknya potensi wisata di Pamekasan, masih terdapat problematika dalam pengembangan wisata. Pengembangan dan pemeliharaan pada obyek-obyek wisata maupun prasarana penunjang pariwisata yang masih minim menyebabkan kontribusi pengunjung belum maksimal. Padahal jika potensi tersebut dapat dikelola secara maksimal dapat menjadi pemasukan PAD Kabupaten Pamekasan.

Sehingga dengan adanya permasalahan yang menjadi kendala dalam pengembangan wisata, perlu adanya terobosan baru guna meminimalisir problematika yang terjadi. Salah satu hal yang dapat dilakukan yaitu dengan cara memanfaatkan wakaf produktif sebagai upaya pengembangan wisata. Melihat wakaf secara historis,

\footnotetext{
${ }^{5}$ Dewi Silvia, "Implementasi Kebijakan Tentang Pengembangan Destinasi Wisata Situs Astana Gede Kawali Oleh Dinas Pariwisata Kabupaten Ciamis", Jurnal Ilmiah Ilmu Administrasi Negara, Volume 6, Nomor 3, (September, 2019), 1.

${ }^{6}$ Khotibul Umam,dkk, "Strategi Pengembangan Agroekowisata Jambu Air Di Kecamatan Camplong Kabupaten Sampang", Jurnal IImiah Mahasiswa AGROINFO GALUH Volume 6, Nomor 3,(September 2019),457-458.
} 
sesungguhnya telah mengajarkan umat Islam akan pentingnya sumber ekonomi yang terus menerus guna menjamin berlangsungnya kesejahteraan di masyarakat.

\section{TINJAUAN PUSTAKA}

Wakaf

Secara bahasa, wakaf adalah "waqafa-ya qifu-waqfan” yang berarti tegak berdiri, menahan, lawan dari kata al-julus (duduk). Menurut syariat, wakaf adalah menahan harta yang mungkin bisa dimanfaatkan namun zat barangnya tetap utuh, dengan memastikan penggunaan barangnya pada perkara yang mubah. Dalam definisi lain, para ulama ahli fiqih saling berbeda pendapat dalam mendefinisikan wakaf. Imam Ahmad bin Hambal dan Imam Asy Syafi'i berpendapat bahwa wakaf adalah melepaskan harta yang diwakafkan dari kepemilikan wakif, setelah sempurna prosedur perwakafan, wakif tidak boleh melakukan apa saja terhadap harta yang diwakafkan seperti perlakuan pemilik dengan cara pemiliknya kepada yang lain, baik tukar-menukar atau tidak. Menurut pasal 1 Undang-Undang Nomor 41 Tahun 2004 menjelaskan bahwa definisi wakaf adalah perbuatan hukum wakif untuk memisahkan dan/atau menyerahkan sebagian harta benda miliknya untuk dimanfaatkan selamanya atau untuk jangka waktu tertentu sesuai dengan kepentingannya guna keperluan ibadah dan atau kesejahteraan umum menurut syariah. ${ }^{7}$

Wakaf merupakan suatu tindakan pemanfaatan harta benda wakaf yang dilakukan oleh wakif baik berupa benda bergerak maupun tidak bergerak yang secara hukum memenuhi syarat dan bertujuan untuk kesejahteraan umat. ${ }^{8}$ Wakaf sebagai instrument untuk kesejahteraan umat yang pertama kali dilakukan oleh Umar bin al Khatthab seizin Rasulullah SAW. Pada saat itu, Umar mempunyai sebidang kebun yang subur dan produktif di Khaibar. Melihat wakaf secara historis, sesungguhnya telah mengajarkan umat Islam akan pentingnya sumber ekonomi yang terus menerus guna menjamin berlangsungnya kesejahteraan di masyarakat. Wakaf sebagai instrumen ekonomi yang memberi kehidupan bagi pengelolanya dan masyarakat. Bukan sebaliknya, wakaf hanya menjadi beban pengelola dan menuntut uluran tangan kedermawanan dari masyarakat. Wakaf pada masa sahabat telah menjadi sumber ekonomi dan pembiayaan untuk pengembangan ilmu pengetahuan. ${ }^{9}$

\section{Macam-macam wakaf}

\footnotetext{
${ }^{7}$ Resfa Fitri dan Heni P Wilantoro, "Analisis Prioritas Solusi Permasalahan Pengelolaan Wakaf Produktif (Studi Kasus Kabupaten Banjarnegara)", Jurnal Al-Muzara'ah Vol. 6 No. 1, 2018. Hal. 43

${ }^{8}$ Hujriman, Hukum Perwakafan di Indonesia (Sleman: DeePublish, 2018), 5.

${ }^{9}$ Veithzal Rivai Zainal, "PENGELOLAAN DAN PENGEMBANGAN WAKAF PRODUKTIF”, Volume 9 No. 1 Edisi Januari 2016 Hal 1
} 
Bila ditinjau dari produktivitas wakaf, maka wakaf dapat dibagi menjadi dua macam, yaitu: Pertama wakaf produktif, yaitu wakaf yang dikelola untuk kegiatan produktif dan hasilnya dimanfaatkan untuk kepentingan umum. Yakni wakaf yang dikelola untuk kegiatan yang produktif yang menghasilkan nilai ekonomi yang kemudian hasilnya diberikan sesuai dengan tujuan wakaf, seperti wakaf untuk pertanian, perikanan, perkebunan, ruko, dan lain sebagainya, Kedua wakaf konsumtif, yaitu wakaf yang tidak dipergunakan untuk aktivitas yang produktif. Yakni wakaf yang pokok barangnya langsung digunakan sesuai dengan tujuan wakaf, seperti wakaf yang diperuntukan untuk masjid, untuk sekolah, dan lain sebagainya

Pasal 16 UU Nomor 41 Tahun 2004 membagi harta jenis wakaf menjadi dua macam, yaitu: Pertama Benda tidak bergerak, yaitu meliputi hak atas tanah, bangunan, atau bagian bangunan yang berdiri di atas tanah, tanaman, atau benda lain yang terkait dengan tanah dan benda tidak begerak lainya yang sesuai dengan ketentuan syariah., Kedua benda bergerak, yaitu meliputi uang, logam mulia, surat-surat berharga, hak atas kekayaan intelektual, kendaraan, hak sewa, dan benda bergerak lainnya yang sesuai dengan ketentuan syariah. ${ }^{10}$

Jika kita fokuskan ke wakaf produktif dengan melihat Potensi Wakaf bahkan mencapai sebesar Rp. 11,4 T per tahun yang terdiri dari 145 Lembaga Wakaf (Badan Wakaf Indonesia, 2016), maka wakaf produktif memiliki dua dimensi yaitu dimensi religi dan dimensi sosial ekonomi. Dimensi religi berarti wakaf yang dilaksanakan merupakan anjuran Allah SWT yang perlu dilakukan oleh setiap muslim yang merupakan bentuk ketaatan seorang muslim kepada Allah. Wakaf bukanlah sedekah, tetapi lebih besar ganjaran dan manfaatnya terutama bagi diri wakif (pelaku wakaf), karena wakaf terus mengalir pahalanya selamanya. Dimensi sosial ekonomi adalah karena dalam prakteknya, para pemilik harta wakaf mengulurkan tangannya untuk membantu kesejahteraan manusia.

Wakaf produktif yang dapat diartikan sebagai wakaf yang asetnya, apabila dikelola dapat memberikan keuntungan secara ekonomis yang dapat berupa tanah-tanah perkebunan/pertanian uang dan macam-macam benda bergerak dan tidak bergerak, perlu lebih ditingkatkan manfaatnya dengan membuat mekanisme dan strategi yang lebih terarah. Wakaf produktif merupakan inovasi dalam keuangan Islam, yang membuka peluang penciptaan investasi di bidang keagamaan, pendidikan serta pelayanan sosial. Disamping itu wakaf produktif (uang) dapat berfungsi sebagai investasi yang strategis

${ }^{10}$ Resfa Fitri dan Heni P Wilantoro, Analisis Prioritas Solusi Permasalahan Pengelolaan Wakaf Produktif (Studi Kasus Kabupaten Banjarnegara), Jurnal Al-Muzara'ah Vol. 6 No. 1, 2018. Hal. 44 
untuk menekan angka kemiskinan dan menangani ketertinggalan di bidang ekonomi, pendidikan, kesehatan dan sebagainya. ${ }^{11}$

\section{Pemberdayaan Ekonomi Dalam Perspektif Islam}

Pemberdayaan dalam bahasa arab disebut sebagai tamkin. Kata tamkin dalam kamus-kamus besar merupakan bentuk mashdar dari fi'il (kata kerja) makkana. Kata tersebut memiliki arti yang sama dengan amkana. Kata tamkin menunjukkan atas kemampuan melakukan sesuatu kekokohan, memiliki kekuatan, kekuasaan, pengaruh, dan memiliki kedudukan atau tempat, baik itu bersifat hissi (dapat dirasakan/materi) atau bisa bersifat ma'nawi. ${ }^{12}$ Pemberdayaan dapat diartikan sebagai upaya untuk memberikan daya atau penguatan kepada masyarakat. Istilah pemberdayaan juga dapat diartikan sebagai upaya memenuhi kebutuhan yang diinginkan oleh individu, kelompok, dan masyarakat luas agar mereka memiliki kemampuan untuk melakukan pilihan dan mengotrol lingkungannya supaya dapat memenuhi kebutuhannya, termasuk aksebilitasnya terhadap sumber daya yang terkait dengan pekerjaannya,aktivitas sosialnya, dan lain-lain.

Sehingga dari beberapa pengertian mengenai pemberdayaan,maka dapat disimpulkan bahwasanya pemberdayaan merupakan upaya memberikan kekuatan kepada orang-orang untuk mempunyai kekokohan dan menjadi berdaya sehingga mempunyai pengaruh agar selalu meningkatkan kualitas hidupnya.

Pemberdayaan yang kini gencar dilakukan oleh Pemerintah dalam program pengentasan kemiskinan adalah pembangunan pada masyarakat desa yang mana merupakan suatu proses dimana orang-orang secara bersama-sama untuk memperbaiki keadaan perekonomian sosialdan kebudayaan dalam masyarakat yang bersangkutan,mengintegrasikan masyarakat dalam kehidupan bangsa yang dapat membantu dalam membangun bangsa dan negara. ${ }^{13}$

Masyarakat merupakan sebuah sistem yang saling membutuhkan dan saling mendukung. Islam memdorong pelaksanaan pemberdayaan masyarakat melalui tiga prinsip utama yaitu prinsip ukhuwah, ta'awun, dan persamaan derajat. ${ }^{14}$ Prinsip ukhuwah berarti persaudaraan dimana bahwasanya tiap-tiap muslim saling bersaudara. Rasa persaudaraan menjamin adanya rasa empati dan merekatkan silaturahim dalam masyarakat. Dalam konteks pemberdayaan, ukhuwah merupakan motif yang mendasari seluruh upaya pemberdayaan masyarakat. Rasulullah memiliki visi agar sesama umat muslim saling menolong dan saling menanggung kesulitan secara bersama. Islam

\footnotetext{
${ }^{11}$ Dharma Satyawan, ANALISIS STRATEGI PENGELOLAAN WAKAF PRODUKTIF DI INDONESIA, Vol.5 No.2 Juli 2018 hal 50.

${ }^{12}$ Yulizar D Sanrego Moch Taufik, Fiqih Tamkin (Jakarta: Qisthi Press, 2015), 75-76.

${ }^{13}$ Irawan M. Suparmoko, Ekonomi Pembangunan (Yogyakarta: BPFE, 208M), 308.

${ }^{14}$ Ulfi Putra Sany, "Prinsip-Prinsip Pemberdayaan Masyarakat Dalam Perspektif Al Qur'an," Jurnal Ilmu Dakwah 39, no. 1 (24 Oktober 2019): 34, https://doi.org/10.21580/jid.v39.1.3989.
} 
mendorong pemeluknya untuk meringankan beban sesamanya dan menamkan kepedulian dalam diri pemeluknya.

Prinsip ta'awun yaitu bahwa Allah SWT mendorong manusia untuk saling tolongmenolong sesamanya. Sehingga prinsip ini merupakan prinsip yang utama dalam pelaksanaan pemberdayaan masyarakat. Prinsip ta'awun atau tolong menolong merupakan sebuah sinergi antara berbagai pihak yang berkepentingan demi terwujudnya pemberdayaan yang optimal.

Ketiga, prinsip persamaan derajat antar umat manusia. Islam telah memproklamirkan persamaan derajat antar manusia sejak 14 abad yang lalu. Kemuliaan yang ada di sisi Allah hanyalah berdasarkan iman dan takwa. Pada dasarnya perbedaan harta dan kekayaan tidak menjadi sumber perpecahan, akan tetapi menjadi wasilah untuk tolong menolong dan saling membantu.

\section{METODE PENELITIAN}

Penelitian ini menggunakan metode penelitian kualitatif dengan pendekatan deskriptif. Jenis data yang digunakan dalam penelitian ini adalah data sekunder dengan teknik pengumpulan data menggunakan buku referensi, artikel dalam jurnal ilmiah dan lain-lain yang berhubungan dengan kajian terkait. Serangkaian kegiatan yang berkaitan dengan studi pustaka ini kemudian dibaca, dicatat, serta diolah menjadi bahan penelitian. Teknik pengumpulan data juga menggunakan teknik documenter yang dilakukan dengan membaca arsip hasil laporan-laporan penelitian sebelumnya yang sesuai dengan permasalahan yang ada. Data-data yang telah dikumpulkan kemudian diolah sehingga diperoleh konsep dengan langkah editing, organizing, dan finding.

\section{HASIL DAN PEMBAHASAN}

\section{Potensi Pariwisata Terhadap Perekonomian}

Pariwisata merupakan salah satu faktor penting dalam perkembangan perekonomian di Indonesia, salah satunya di Kabupaten Pamekasan. Tujuan pengembangan wisata akan berhasil dengan optimal apabila ditunjang oleh potensi daerah yang berupa objek wisata.Kabupaten Pamekasan merupakan salah satu Kabupaten yang memiliki jumlah potensi wisata yang cukup banyak banyak seperti wisata pantai. Akan tetapi kawasan wisata yang terdapat di Kabupaten Pamekasan belum dimanfaatkan dan dikembangkan secara maksimal. Belum adanya pengelolaan yang baik walaupun memiliki banyak potensi wisata mengakibatkan objek-objek wisata yang seharusnya dapat dikembangkan menjadi terabaikan dan tidak terpelihara sehingga terjadi penurunan kulaitas lingkungan. Dari penurunan kualitas lingkungan tersebut menyebabkan ketidakstabilan jumlah pengunjung tiap tahunnya. Menurut Kepala Dinas Pariwisata dan Kebudayaan Kabupaten Pamekasan mencatat jumlah pengunjung tempat wisata pada tahun 2019 yang bekerja sama dengan Pemkab yaitu sebesar 102.979. Angka 
ini memang mengalami peningkatan dari tahun sebelumnya, akan tetapi jumlahnya tidak banyak yaitu hanya sebesar 5 persen. Padahal dengan adanya potensi yang dimiliki dapat mendorong meningkatnya perekonomian daerah sekitar, hal ini karena pariwisata merupakan ujung tombak dari kemajuan perekonomian. Untuk melakukan pengelolaan dan pengembangan objek wisata dibutuhkan suatu metode atau analisa agar dalam pelaksanaan dan pengembangan pariwisata dapat dilakukan dengan baik. Pertumbuhan pariwisata merupakan sektor andalan karena didukung oleh kekayaan sumber daya alam dan keragaman budaya serta adat istiadat. Sebagai sumber pendapatan devisa negeri atau wilayah, pariwisata merupakan bidang yang vital dalam perekonomian, pengembangan socio-cultural, dan memasarkan citra positif suatu daerah.

\section{Optimalisasi Wakaf Produktif Terhadap Pemberdayaan Ekonomi}

Secara umum wakaf di Indonesia hanya berupa benda-benda konsumtif, bukan barang produktif. Hal ini terlihat pada adanya masjid, sekolah, panti asuhan dan sebagainya. Sehingga perkembangan wakaf di Indonesia kurang memberi manfaat secara ekonomis bagi masyarakat. Minimnya regulasi yang mengatur tentang perwakafan, menyebabkan wakaf di Indonesia mengalami stagnasi. Untuk itu pada tahun 2001 beberapa praktisi ekonomi Islam mulai mengusung paradigma baru ke tengah masyarakat mengenai konsep baru pengelolaan wakaf uang untuk peningkatan kesejahteraan umat. Ternyata konsep tersebut menarik dan mampu memberikan energi untuk menggerakkan perkembangan wakaf. Kemudian pada tahun 2002, Majelis Ulama Indonesia (MUI) menyambut konsep tersebut dengan mengeluarkan fatwa yang membolehkan wakaf uang (waqfal-nuqud). Fatwa MUI tersebut kemudian diperkuat oleh hadirnya Undang-Undang No. 41 Tahun 2004 Tentang Wakaf yang menyebutkan bahwa wakaf tidak hanya benda tidak bergerak, tetapi juga dapat berupa benda bergerak, seperti uang. Selain itu, diatur pula kebijakan perwakafan di Indonesia, mulai dari pembentukan nadzir (lembaga wakaf/BWI)24 sampai dengan mamajemen pengelolaan harta wakaf. Lahirnya Undang-Undang No. 41 Tahun 2004 Tentang Wakaf dan Fatwa Majelis Ulama Indonesia berikut peraturan turunannya merupakan titik tolak peningkatan pemberdayaan potensi wakaf di Indonesia ke arah yang lebih produktif. Pemberdayaan yang dimaksud mengandung pemahaman yang komprehensif dengan dimensi yang sangat luas. Benda wakaf mencakup harta tidak bergerak maupun yang bergerak, dikelola oleh nazir yang berbentuk lembaga khusus bidang perwakafan, dilakukan pengembangan harta wakaf, dan pendistribusiannya pun tidak terbatas untuk pendirian tempat ibadah dan sosial keagamaan saja. Pengembangan wakaf telah menggunakan manajeman yang profesional, dalam artian mempunyai cara atau metode yang konseptual mengenai pemberdayaan atas sumber daya keseluruhan, yang operasionalisasinya dilaksanakan secara terancana, terorganisasi, teratur, tertib, terkordinasi, serta terkendali sehingga tujuan atau sasaran dapat tercapai secara efektif dan efisien. Semakin luasnya pemahaman dan pemberdayaan harta wakaf ini sangat penting, terutama jika dikaitkan 
dengan konsep pengembangan wakaf produktif dalam meningkatkan perekonomian umat. Peran pengelola wakaf pun semakin luas, tidak hanya sekedar menjaga dan melakukan halhal yang bersifat rutinitas, melainkan juga mencari inovasi-inovasi baru dalam rangka mengembangkan dan memberdayakan aset wakaf tersebut. Untuk itu, perlu ada upaya perbaikan yang bertujuan untuk membenahi manajemen wakaf dan menghilangkan sebab-sebab keterpurukan manajemen wakaf. Adapun manjemen pengelolan wakaf produktif dapat dijelaskan melalui skema berikut ini:

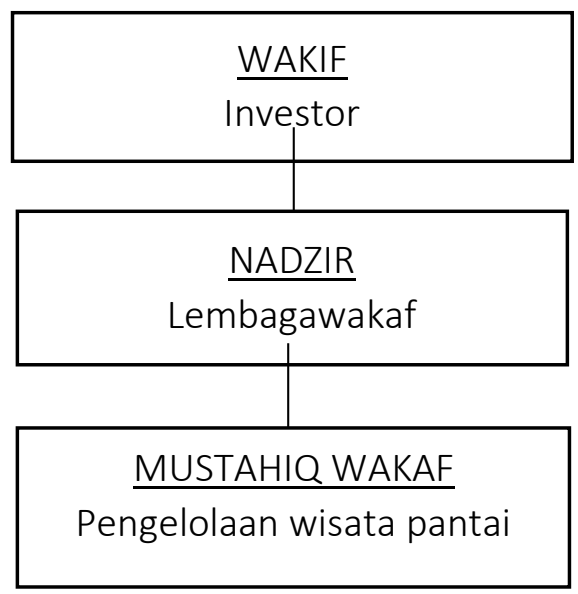

Konsep ini diharapkan dapat memberikan tiga kontribusi, yaitu pertama, mengembangkan benda wakaf yang asalnya hanya terfokus pada tanah, akan tetapi juga bisa berbentuk uang tunai. Kedua, bahwasanya harta wakaf boleh dikelola dan dikembangkan. Dengan demikian harta wakaf akan semakin bertambah dan biaya perawatan tidak lagi dibebankan kepada masyarakat. Ketiga, pengembangan dalam hal mustahik wakaf, dimana penerima tidak hanya kaum duafa ataupun tempat-tempat ibadah, melainkan juga untuk pengembangan SDM seperti pengembangan tempat wisata. Undang-Undang No. 41 Tahun 2004 telah mengakui keabsahan lembaga yang bergerak di bidang wakaf. Wakaf merupakan sebagian harta wakif yang di serahkan kepada nazhir untuk dikelola secara optimal guna mewujudkan peran sosial-ekonomi umat. Paradigma dalam menjadikan manfaat asset wakaf hanya untuk kepentingan ibadah atau sosial saja seperti pembangunan masjid, mushola, panti asuhan, sekolah, makam dan lainnya. Pola paradigma masyarakat yang masih tradisional tersebut harus kita rubah karena wakaf sendiri dapat membangun perekonomian yang baik untuk kemaslahatan umat. Pengelolaan wakaf produktif yang professional harus kita bangun untuk mengembangkan unit usaha yang lebih inovatif yang hasil peruntukkan wakaf untuk kemaslahatan umat. Dengan adanya pengembangan wakaf produktif ini diharapkan dapat memberdayakan perekonomian masyarakat. Sehingga dengan berkembangnya wisata pantai melalui pengoptimalan wakaf produktif dapat memberikan lapangan pekerjaan baru bagi masyarakat sekitar pantai, yang nantinya pemberdayaan ekonomi akan lebih meningkat. Karena berdasarkan data dari BPS (badan pusat statistika) pada bulan maret tahun 2018 
dimana penduduk dengan pengeluaran perkapita perbulan dibawah garis kemiskinan sebesar 25.950.000 jiwa atau sebesar 9,8\%.

\section{KESIMPULAN}

Salah satu masalah sosial yang sering terjadi di Indonesia yaitu kemiskinan sehingga perlu dilakukan berbagai upaya untuk menangani permasalahan tersebut. Salah satu hal yang dapat dilakukan guna memberdayakan perekonomian dengan tujuan tercapainya kesejahteraan yaitu dengan pengoptimalan kawasan wisata. Pada era globalisasi saat ini pariwisata menjadi salah satu aspek penting terhadap kemajuan suatu negara. Setiap negara terus berusaha untuk memanfaatkan potensi yang ada untuk menarik wisatawan berkunjung ke negeranya. Untuk mengoptimalkan potensi wisata dapat dilakukan melalu konsep wakaf produktif melalui peranan investor. Dimana nantinya wakaf uang tunai akan diproduktifkan melalui peranan nadzir sebagai lembaga zakat sehingga dana yang digunakan dapat digunakan untuk mengoptimalkan pariwisata sehingga kesejahteraan ekonomi, khususnya masyarakat sekitar dapat tercapai. Untuk mewujudkan konsep tersebut diharapkan adanya kerja sama dari para stakeholder untuk mendukung tercapainya suatu tujuan memberdayakan perekonomian.

\section{DAFTAR PUSTAKA}

Awali, Husni dan Farida Rohmah, "Urgensi Pemanfaatan E-Marketing Pada Keberlangsungan UMKM Di Kota Pekalongan Di Tengah Dampak Covid-19" dalam Jurnal Ekonomi dan Bisis Islam, No. 1, Vol. 2, Janurari - Juni 2020.

Azizah, Nur, Fadilah, Igo Fadilah Ilham, Liza Putri Aqidah, Safira Aliyani Firdaus, Setyani Agung Dwi Astuti dan Imam Buchori, "Strategi UMKM untuk Meningkatkan Perekonomian selama Pandemi Covid-19 pada saat New Normal", dalam OECONOMICUS Journal of Economics, No. 1, Vol. 05, December 2020.

Chafeey, Mayer, Internet marketing: Strategi, Implementation and Practice, Jakarta: Prentice hall/finansial times, 2009.

Fitriyani, Ika, Strategi Manajemen Bisnis Pasca Pandemi Covid-19, Jakarta: Press 2020.

Hamid, Suand, Edy, Ekonomi Indonesia dari Sentralisasi ke Desentralisasi, Ctk. Pertama, Yogyakarta: UII Press, 2006.

Ihza, Nur, Khofifah, Dampak Covid-19 Terhadap Usaha Mikro Kecil dan Menengah (UMKM), dalam Jurnal Inovasi Penelitian, No.7, Vol.1 Desember 2020.

Karyani, Rema, Manajemen Kampanye: Paduan Teoritis dan Praktis dalam Mengefektifkan Kampanye Komunikas, Bandung: Aambiosa Rekatam Media, 2004.

Karyani, Rema, Manajemen Kampanye: Paduan Teoritis dan Praktis dalam Mengefektifkan Kampanye Komunikasi, Bandung: Aambiosa Rekatam Media, 2004.

Kotler, Principles of Marketing 15th ed, (New Jersey: Prentice Hall Published, 2012. 
Lestari, The Effect Of Product Quality Toward Interest In. Journal of Business Studies (JOBS), Semarang: Jurusan Administasi Bisnis, Politeknik Negeri Semarang, 2019.

Masriansyah, Luki, "Go Digitial and Customer Relationship Marketing sebagai Strategi Pemulihan Bisnis UMKM yang Efektif dan Efisien di Masa Adaptasi New Normal" dalam Program Studi Magister Manajemen Fakultas Ekonomi dan Bisnis 2020

Mohammed, Internet Marketing: Building Advantage in a Network Economy, New York: McGraw-Hill Companies, 2003.

Nugroho, Adi, E-Commerce Memahami Perdagangan Modern di Dunia Maya, Bandung: Informatika bandung, 2013.

Pratiwi, Intan, Maya, "Dampak Covid-19 Terhadap Perlambatan Ekonomi Sektor UMKM" dalam Jurnal Ners, No. 2 Vol. 04, April 2020.

Purwana, Pemanfaatan Digital Marketing Bagi Usaha Mikro, Kecil, dan Menengah (UMKM) di Kelurahan Malaka Sari, Duren Sawit. Jurnal Pemberdayaan Masyarakat Madani (JPMM), 2017.

Rapitasari, "Digital marketing Berbasis Aplikasi Sebagai Strategi Meningkatkan Kepuasaan Pelanggan" dalam Jurnal Cakrawala, No.10 Vol Februari 2016.

Rohimah, "Era Digitalisasi Media Pemasaran Online dalam Gugurnya Pasar Ritel Konvensional. KANAL” dalam Jurnal Ilmu Komunikasi, No. 6 Vol. Februari 2009.

Rosita, Rahmi, "Pengaruh Pandemi Covid-19 Terhadap Umkm Di Indonesia”, dalam Jurnal Lentera Bisnis, No. 2, Vol. 09, November 2020.

S, Sukirno, Makro ekonomi Teori Pengantar, Jakarta: Rajawali Pers, 2016.

Setiawati, Pengaruh Strategi Pemasaran Online Terhadap Peningkatan Laba Umkm: Strategi Komunikasi Pemasaran, Bandung: Alfabeta, 2017.

Sulis, Hasil Wawancara dengan owner laundry, 03 Mei 2021.

Sumadi, "Menakar Dampak Fenomena Pandemi Covid-19 Terhadap Perbankan Syariah, dalam Jurnal hokum Ekonomi Syariah", No. 2, Vol. 3 Oktober 2020.

Supriatna, Eman, “Wabah Corona Virus Disease Covid 19 Dalam Pandangan Islam," dalam Jurnal Sosial \& Budaya Syar'I, No. 01,Vol. Juni 2020.

Suyanto, M, Strategi Periklanan pada E-Commerce Perusahaan Top Dunia, Yogyakarta: andi. 200.

Tambunan,Tulus T.H, UMKM di Indonesia, Bogor: Ghalia Indonesia, 2009.

Thaha, Firdaus, Abdurrahman, “Dampak Covid-19 Terhadap Umkm Di Indonesia”, dalam Jurnal Brand, No. 1,Vol. 02, Juni 2020.

Triyono, Budi, Potret Belanja Online di Indonesia, (Jakarta: Pusat Data dan Sarana Informatika, 2013. 